\title{
Effect of different reinforcements on composite-strengthening in aluminium
}

\author{
A K KURUVILLA, V V BHANUPRASAD, K S PRASAD and Y R \\ MAHAJAN \\ Defence Metallurgical Research Laboratory, P.O. Kanchanbagh, Hyderabad 500258 , \\ India \\ MS received 26 May 1989
}

\begin{abstract}
In the development of metal-matrix composites, reinforcements of aluminium and its alloys with ceramic materials has been pursued with keen interest for quite sometime now. However, a systematic comparison of the effect of different reinforcements in powder-processed aluminium and its alloys is not freely available in the published literature. This study examines the influence of $\mathrm{SiC}, \mathrm{TiC}, \mathrm{TiB}_{2}$ and $\mathrm{B}_{4} \mathrm{C}$ on the modulus and strength of pure aluminium. $\mathrm{B}_{4} \mathrm{C}$ appears slightly superior as a reinforcement when comparing the effect of $\mathrm{SiC}, \mathrm{TiC}, \mathrm{B}_{4} \mathrm{C}$ and $\mathrm{TiB}_{2}$ on specific modulus and specific strength values of composites. However, $\mathrm{TiC}$ appears to be a more effective reinforcement, yielding the best modulus and strength values among those considered in this study. The differences in thermal expansion characteristics between aluminium and the reinforcements do not seem to explain this observation. The other advantage of $\mathrm{TiC}$ is that it is economically a more viable candidate as compared to $\mathrm{B}_{4} \mathrm{C}$ and $\mathrm{TiB}_{2}$ for reinforcing aluminium alloys. It is suggested that the superior effect of $\mathrm{TiC}$ as a reinforcement is probably related to the high integrity of the bond at the Al-TiC interface.
\end{abstract}

Keywords. Aluminium-matrix composite; silicon and metal carbides; powder metallurgy; thermal expansion.

\section{Introduction}

Discontinuously reinforced aluminium and aluminium alloy composites are increasingly being developed and used in a variety of applications. By and large, ceramic materials in the form of particulates, whiskers or fibres are used for the fabrication of these composites. A great deal of attention has been focussed on the development of aluminium alloys containing $\mathrm{SiC}$ in the form of particulates or whiskers (Divecha et al 1981; Nair et al 1985; Dolowy 1986). The incorporation of $\mathrm{SiC}$ reinforcements results in an improvement in the physical and mechanical properties as compared to those of the unreinforced matrix alloy. These improved properties include high strength and specific modulus, high creep strength, high fatigue resistance, low thermal expansion and good thermal stability.

The major approaches for producing these composites are powder metallurgy (extrusion), squeeze infiltration of ceramic preforms and compocasting techniques. Of these various routes, the powder metallurgy technique is very popular, particularly for the fabrication of particulate-reinforced composites, because it results in composites with superior properties as compared to cast composites.

$\mathrm{SiC}$ is most widely used for composite strengthening of aluminium alloys. The high modulus and strength of $\mathrm{SiC}$ and its compatibility with aluminium makes it a very attractive choice for reinforcement. $\mathrm{B}_{4} \mathrm{C}$ also finds application in composite-strengthening of aluminium alloys because of its low density (as compared to many other reinforcements) and reasonably high modulus of elasticity 
(Girot et al 1987). The possibility of producing fine dispersions of materials like $\mathrm{TiB}_{2}$ via reactive sintering in an aluminium alloy matrix (Christodonlon et al 1986) makes this an attractive choice for reinforcement as well. Table 1 lists the variety of processes used in reinforcing aluminium with different reinforcements. However, there has been no report of any systematic study where different reinforcements have been evaluated using a single processing technique.

In the light of these observations, this study was undertaken to compare the effect of four potential ceramic reinforcements, namely, $\mathrm{SiC}, \mathrm{B}_{4} \mathrm{C}, \mathrm{TiC}$ and $\mathrm{TiB}_{2}$ in commercially pure aluminium. These composites were fabricated by powder processing. Such a study would help in making cost-effective choice of reinforcements for aluminium alloy matrices.

\section{Experimental procedure}

The composites were fabricated using powder metallurgy techniques. The particulate reinforcements were $\mathrm{SiC}, \mathrm{B}_{4} \mathrm{C}, \mathrm{TiB}_{2}$ and $\mathrm{TiC}$, the sizes of which are given in table 2. A consistent volume fraction of $20 \%$, was used for all these reinforcements. Air-atomized aluminium powder having an average particle size of $50 \mu \mathrm{m}$ was used as the matrix material. The powder was supplied by the Metal Powder Co., Madurai, India.

The processing steps are schematically shown in figure 1. Initial processing involved deagglomeration of the reinforcement particulates in a polar solvent medium using an agate pot mill. This was followed by wet mixing of aluminium

Table 1. Variety of reinforcements and manufacturing routes for aluminium matrix composites.

\begin{tabular}{lll}
\hline Material & Process & Reference \\
\hline $\mathrm{Al}+20 \% \mathrm{SiC}_{p}$ & PM & Arsenault and Shi (1988) \\
$\mathrm{Al}+20 \% \mathrm{~B}_{4} \mathrm{C}$ & Conform extrusion & Slater and Coon (1988) \\
$\mathrm{Al}+\mathrm{Mg}-\mathrm{Be}+18 \% \mathrm{TiB}_{2}$ & Compocasting & Mccoy et al (1988) \\
$7075 \mathrm{Al}+15 \% \mathrm{TiB}_{2}$ & $\mathrm{XD}^{\mathrm{TM}}$ & Christodoulou et al (1986) \\
$\mathrm{Al}-\mathrm{Zn}-\mathrm{Mg}-\mathrm{Cu}-\mathrm{Co}+15 \% \mathrm{TiC}$ & $\mathrm{PM}$ & Macdonald and Ransley (1954)
\end{tabular}

*PM-powder metallurgy; $\mathrm{XD}^{\mathrm{MM}}-\mathrm{Martin}$ Marietta's proprietary process.

Table 2. Characteristics of various ceramic reinforcements.

\begin{tabular}{|c|c|c|c|c|c|c|c|}
\hline $\begin{array}{l}\text { Rein- } \\
\text { force- } \\
\text { ment }\end{array}$ & $\begin{array}{l}\text { Particle } \\
\text { size } \\
(\mu \mathrm{m})\end{array}$ & $\begin{array}{c}\text { Density }^{a} \\
(\mathrm{~g} / \mathrm{cc})\end{array}$ & $\begin{array}{c}E \\
(\mathrm{GPa})\end{array}$ & $\begin{array}{c}\text { CTE } \\
\left(\times 10^{-6} / 9 \mathrm{C}\right)\end{array}$ & $\begin{array}{l}\text { Manufac- } \\
\text { turer }\end{array}$ & Grade & $\begin{array}{c}\text { Relative } \\
\text { cost } \\
\text { factor }\end{array}$ \\
\hline $\mathrm{B}_{4} \mathrm{C}$ & $1 \cdot 2$ & 2.52 & $480^{b}$ & $45^{\mathrm{c}}$ & $\begin{array}{l}\text { Hermann } \\
\text { C-Starck }\end{array}$ & HP & $6 \cdot 15$ \\
\hline $\mathrm{TiC}$ & $1 \cdot 4$ & 492 & $320^{b}$ & $7 \cdot 4^{c}$ & $\begin{array}{l}\text { Hermann } \\
\text { C-Starck }\end{array}$ & Standard & 1.98 \\
\hline $\mathrm{SiC}$ & $1 \cdot 5$ & $3 \cdot 21$ & $480^{b}$ & $4 \cdot 7^{\mathrm{c}}$ & $\begin{array}{l}\text { Superior } \\
\text { Graphite }\end{array}$ & 056 & 1.0 \\
\hline $\mathrm{TiB}_{2}$ & 4 & $4 \cdot 52$ & $430^{\mathrm{a}}$ & $8 \cdot 28^{a}$ & $\begin{array}{l}\text { Elektroschmelz- } \\
\text { werk Kempten } \\
\text { GmbH }\end{array}$ & - & 2.9 \\
\hline
\end{tabular}

${ }^{\mathrm{a}}$ Lynch et al (1966); ${ }^{\mathrm{b}}$ Girot et al (1987); 'Kingery et al (1976). 


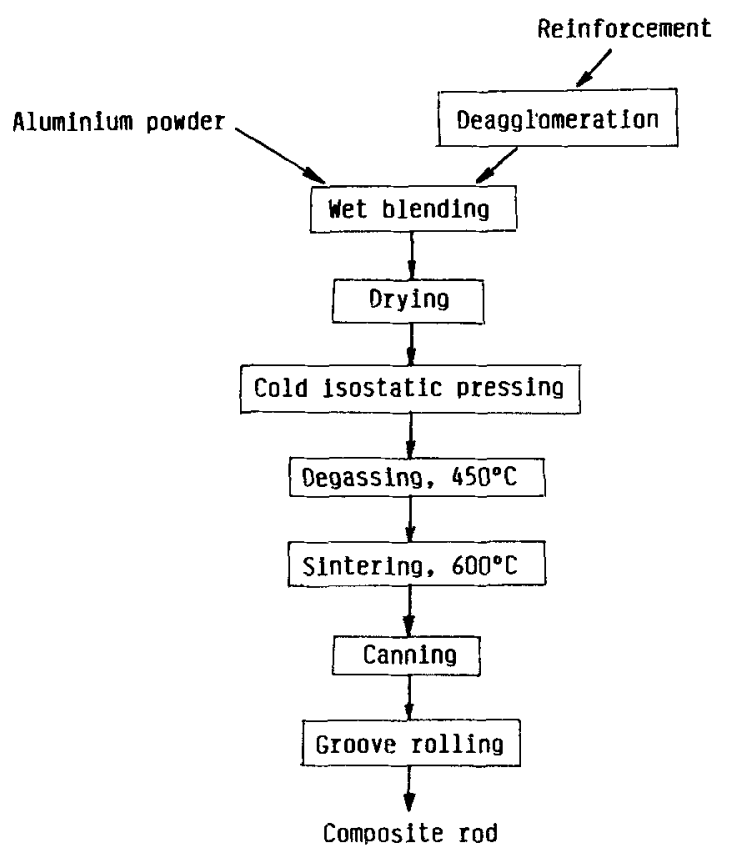

Figure 1. Process route for the fabrication of composites.

powder with the deagglomerated particulate slurry by horizontal tumbling in a roller mill. The mixture thus obtained was dried, cold isostatically pressed, degassed at $450^{\circ} \mathrm{C}$ in vacuum and sintered at $600^{\circ} \mathrm{C}$.

The sintered compacts were rolled at $500^{\circ} \mathrm{C}$ using a canning process which yielded composite rods of $6-8 \mathrm{~mm}$ diameter. The effective reduction in area of the composite on rolling was $95 \%$ which rendered this consolidation step effective.

Microstructural evaluation involved metallographic polishing and preparation of the composite samples and examination under the scanning electron microscope. The elastic moduli of the composites were measured on machined samples using a resonance technique (by analysing the vibrational behaviour of the sample following an impulse excitation) (Chakraborty et al 1989).

The densities of these composites were measured by water displacement. Tensile test samples having a gauge diameter of $4 \mathrm{~mm}$ and a gauge length of $25 \mathrm{~mm}$ were machined from the rods and tested at a strain rate of $6.6 \times 10^{-4} / \mathrm{s}$.

\section{Results and discussion}

The resultant composite microstructures of the four composites are shown in figure 2. These are SEM micrographs of metallographically polished samples. The reinforcement particulates, in all the four cases, appear well-distributed in the matrix and the microstructure does not reveal any porosity. This implies that the processing sequence, including sintering and rolling, has been extremely effective in producing integral composites. The particle sizes and distribution of $\mathrm{TiC}, \mathrm{B}_{4} \mathrm{C}$ and $\mathrm{SiC}$ are comparable whereas those of $\mathrm{TiB}_{2}$ are slightly larger. The average particle sizes of the reinforcements are shown in table 2 . 

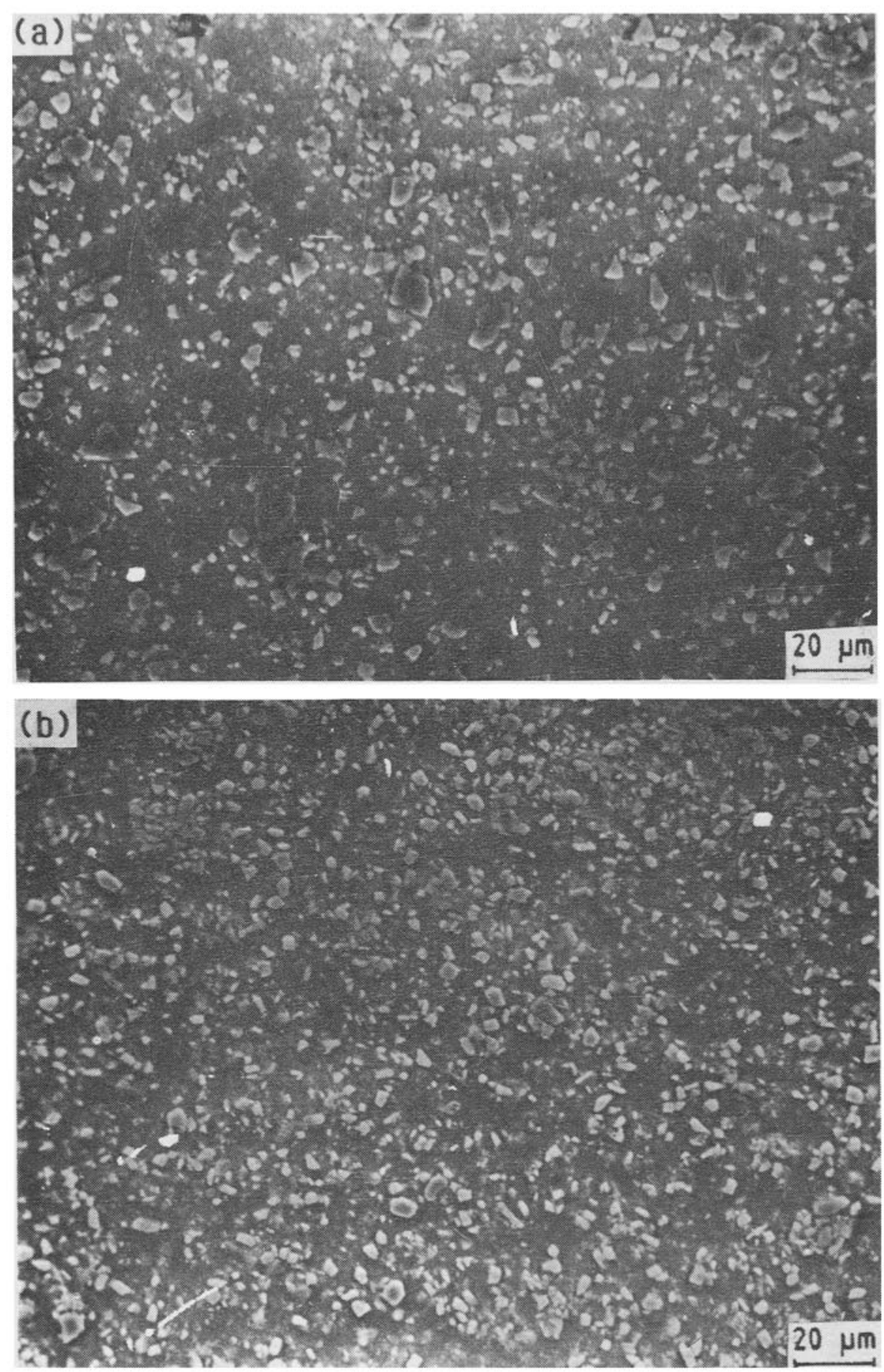

Figure 2. SEM micrographs of composites, (a) $\mathrm{Al} / \mathrm{SiC}$, (b) $\mathrm{Al} / \mathrm{TiC}$.

The densities of the composites are shown in table 3 . These values lie very close to the theoretical values, thus confirming the efficiency of the various processing steps and the "sinter + rolling" technique for consolidation of these composites. 

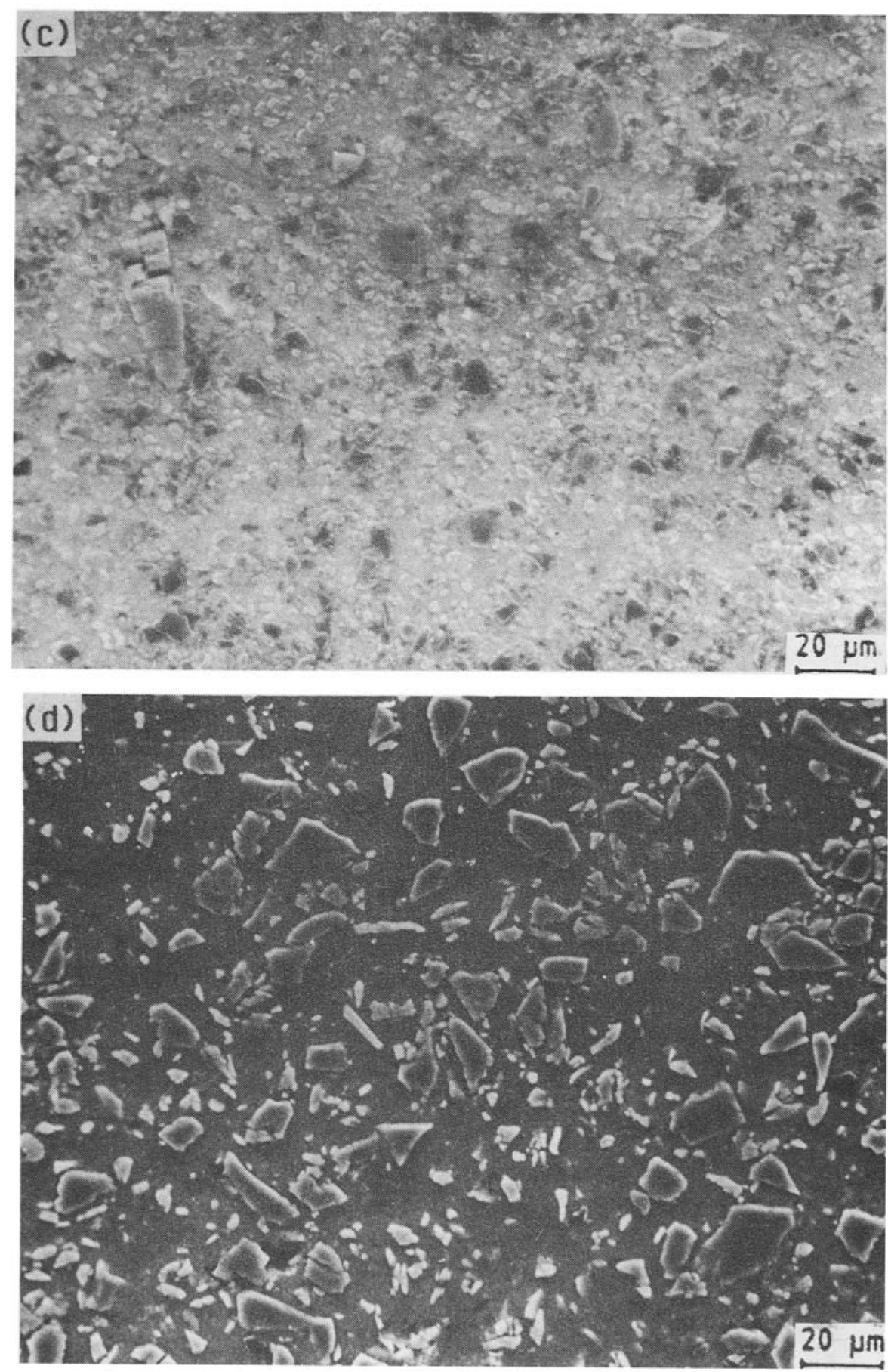

Figure 2. SEM micrographs of composites, (c) $\mathrm{Al} / \mathrm{B}_{4} \mathrm{C}$, (d) $\mathrm{Al} / \mathrm{TiB}_{2}$.

The elastic moduli and specific elastic moduli of the composites are shown in table 3 along with that of pure aluminium for comparison. All the reinforcements considered here improve the elastic moduli of aluminium significantly. The Al/TiC 
Table 3. Mechanical properties of aluminium matrix composites.

\begin{tabular}{|c|c|c|c|c|c|c|c|c|}
\hline Composite & $\begin{array}{c}\text { Density } \\
(\mathrm{g} / \mathrm{cc})\end{array}$ & $\begin{array}{c}E \\
(\mathrm{GPa})\end{array}$ & $\begin{array}{l}\text { ROM-E } \\
\text { (GPa) }\end{array}$ & $\begin{array}{c}\text { Specific } \\
\text { modulus } \\
(\mathrm{GPa} / \\
\mathrm{g} / \mathrm{cc})\end{array}$ & $\begin{array}{c}\mathrm{YS} \\
(\mathrm{MPa})\end{array}$ & $\begin{array}{c}\text { UTS } \\
\text { (MPa) }\end{array}$ & $\begin{array}{l}\text { Specific } \\
\text { UTS } \\
\text { (MPa/ } \\
\mathrm{g} / \mathrm{cc})\end{array}$ & $\begin{array}{c}\text { Elongation } \\
(\%)\end{array}$ \\
\hline Pure Al & $2 \cdot 72$ & 70 & - & $26 \cdot 9$ & 64 & 90 & 33 & 21 \\
\hline $\mathrm{Al} / \mathrm{SiC}$ & 2.77 & 102 & 152 & 36.8 & 117 & 200 & $70-3$ & 10 \\
\hline $\mathrm{Al} / \mathrm{TiC}$ & $3 \cdot 14$ & 116 & 120 & 36.9 & 148 & 233 & $74 \cdot 1$ & 9 \\
\hline $\mathrm{Al} / \mathrm{B}_{4} \mathrm{C}$ & 2.75 & 105 & 152 & 38 & 143 & 208 & $75 \cdot 4$ & $9 \cdot 2$ \\
\hline $\mathrm{Al} / \mathrm{TiB}_{2}$ & 3.05 & 96 & 143 & 31.5 & 121 & 166 & 54.5 & 16 \\
\hline
\end{tabular}

composite has a value of $116 \mathrm{GPa}$ for the elastic modulus as compared to 96,102 and $105 \mathrm{GPa}$, respectively, for $\mathrm{Al} / \mathrm{TiB}_{2}, \mathrm{Al} / \mathrm{SiC}$ and $\mathrm{Al} / \mathrm{B}_{4} \mathrm{C}$ composites. Compared to the elastic modulus of aluminium, which is $70 \mathrm{GPa}$, the $\mathrm{Al} / \mathrm{TiB}_{2}$ composite displays a $37 \%$ higher elastic modulus. Prior work has shown the modulus values of powder-processed $\mathrm{Al} / 20 \% \mathrm{~B}_{4} \mathrm{C}$ to be $96 \mathrm{GPa}$ (Nieh and Chellman 1984) whereas it was shown to be $122 \mathrm{GPa}$ when the processing was by conform extrusion (Slater and Coon 1988). Of the four reinforcements considered here, the contribution of $\mathrm{B}_{4} \mathrm{C}$ appears superior when comparing specific moduli. However, considering that the density of $\mathrm{B}_{4} \mathrm{C}$ is about $50 \%$ that of $\mathrm{TiC}$ and that the specific moduli of $\mathrm{Al} / \mathrm{B}_{4} \mathrm{C}$ and $\mathrm{Al} / \mathrm{TiC}$ are not vastly different, it can be inferred that $\mathrm{TiC}$ is a more potent reinforcement in aluminium. Though the specific moduli of $\mathrm{Al} / \mathrm{TiC}$ and $\mathrm{Al} / \mathrm{SiC}$ are nearly the same, it should be noted that the density of $\mathrm{SiC}$ is only about $65 \%$ that of $\mathrm{TiC}$. The greater effectiveness of $\mathrm{TiC}$ in improving the modulus of aluminium as compared to the other reinforcement, is thus further established.

The elastic moduli predicted by calculations based on the rule of mixtures (using the modulus values for the reinforcements given in table 2) are also shown alongside the observed values in table 3 under the heading ROM-E. The most interesting observation is that the observed value $(116 \mathrm{GPa})$ is closest to the predicted value $(120 \mathrm{GPa})$ in the $\mathrm{Al} / \mathrm{TiC}$ composite. In the $\mathrm{Al} / \mathrm{B}_{4} \mathrm{C}, \mathrm{Al} / \mathrm{SiC}$ and $\mathrm{Al} / \mathrm{TiB}_{2}$ composites, the observed values are considerably lower than the predicted values. Since the rule of mixtures essentially assumes that there is an effective transfer of the load from the matrix to the reinforcement through the interface, the present observation suggests that the interface in the $\mathrm{Al} / \mathrm{TiC}$ composite is superior in some way when compared to the other composites. This is also possible indication of the integrity of the composite and the efficiency of the reinforcement in composite strengthening. This comparison also makes it clear that $\mathrm{TiC}$ is a more potent reinforcement in aluminium when compared to $\mathrm{B}_{4} \mathrm{C}, \mathrm{SiC}$ and $\mathrm{TiB}_{2}$.

The tensile test results are also recorded in table 3 . The strength and ductility (\% elongation) of identically-processed aluminium is also shown for comparison. The $\mathrm{Al} / \mathrm{TiC}$ composite displays a UTS of $233 \mathrm{MPa}$ as compared to 200, 208 and $166 \mathrm{MPa}$, respectively, for $\mathrm{Al} / \mathrm{SiC}, \mathrm{Al} / \mathrm{B}_{4} \mathrm{C}$ and $\mathrm{Al} / \mathrm{TiB}_{2}$ cornposites. Ductilities, expressed as \% elongation, are of the order of about $9-10 \%$ for $\mathrm{Al} / \mathrm{SiC}, \mathrm{Al} / \mathrm{TiC}$ and $\mathrm{Al} / \mathrm{B}_{4} \mathrm{C}$ as compared to $16 \%$ for $\mathrm{Al} / \mathrm{TiB}_{2}$. Slater and Coon (1988) have reported a UTS of $190 \mathrm{MPa}$ for the $\mathrm{Al} / 20 \% \mathrm{~B}_{4} \mathrm{C}$ composite produced by conform extrusion which is lower than the $208 \mathrm{MPa}$ observed in this study. This is indicative of the efficiency of the sinter + rolling sequence used in the consolidation of these composites. Using spray-deposition and hot-rolling $\left(500^{\circ} \mathrm{C}\right)$, Singer and Ozbek 
(1985) have produced $\mathrm{Al} / 22-28 \% \mathrm{SiC}_{p}$ which showed UTS values of $153 \mathrm{MPa}$ as compared to $200 \mathrm{MPa}$ observed here. In addition the spray-deposited and hotrolled product displayed only $1 \%$ elongation before failure. Arsenault and $\mathrm{Wu}$ (1988), however, have reported values of $250 \mathrm{MPa}$ for UTS in $\mathrm{Al} / 20 \% \mathrm{SiC}_{p}$ produced by powder metallurgy. The average particle size of $\mathrm{SiC}_{p}$ used in that study was $0.5 \mu \mathrm{m}$ whereas, in the present, it was $1.5 \mu \mathrm{m}$, which could account for the difference in the strength values. Chellman and Slaughter (1983) have reported a UTS value of $199 \mathrm{MPa}$ for $\mathrm{Al} / 19 \% \mathrm{SiC}_{p}$ which is comparable to the strength obtained in this study. Among the four reinforcements considered, TiC appears to have the maximum ellect in composite strengthening.

Arsenault and Shi (1986) have proposed that the major component of the increase in strength, when reinforcing a matrix, results from the differences in the coefficient of thermal expansion between the matrix and the reinforcement which help to generate interfacial dislocations during heating/cooling while processing. In essence, for a given volume fraction of reinforcement,

$$
\Delta \sigma \alpha \frac{\Delta \mathrm{CTE}}{\text { particle size }}
$$

where $\Delta \sigma$ is the major component of composite strengthening which is proportional to $\triangle C T E$ which is the difference in the coefficient of thermal expansion. Considering the coefficients of thermal expansion of these reinforcements (as shown in table 2), the increase in strength resulting from this component would be maximum for $\mathrm{Al} / \mathrm{SiC}$ and $\mathrm{Al} / \mathrm{B}_{4} \mathrm{C},\left(C T E\right.$ for $\mathrm{Al}$ is $22.4 \times 10^{-6} /{ }^{\circ} \mathrm{C}$ ) followed by $\mathrm{Al} / \mathrm{TiC}$ (the particie sizes are similar-table 2). Since the increase in strength due to other reasons like reduction in subgrain size etc. remain relatively small in all the cases (Arsenault and Shi 1986), the effect that is predicted by this argument is contrary to the observation in this study where maximum strengthening is observed in the $\mathrm{Al} / \mathrm{TiC}$ composite. This would suggest that the effectiveness of $\mathrm{TiC}$ may be related to the interface of $\mathrm{Al}$ and $\mathrm{TiC}$ more than anything else. Though a comparison of hardness values of the reinforcements may be applicable more in the case of continuous reinforcements, it is still worthwhile to note that $\mathrm{TiC}$ is harder (KHN of $3170 \mathrm{~kg} / \mathrm{mm}^{2}$ ) than $\mathrm{B}_{4} \mathrm{C}$ and $\mathrm{SiC}$ (2800 and $2740-2960$ respectively). These three reinforcements have comparable particle sizes in this study.

A comparison of the specific strength shows that the improvement in strength obtained by adding a low density reinforcement like $\mathrm{B}_{4} \mathrm{C}$ as compared to that obtained by adding $\mathrm{TiC}$ (which is 2 times denser than $\mathrm{B}_{4} \mathrm{C}$ ) is only marginal. The $\mathrm{Al} / \mathrm{TiC}$ composite appears to be superior even to the $\mathrm{Al} / \mathrm{SiC}$ composite. These observations, thus reinforce the inference that $\mathrm{TiC}$ is a very potent reinforcement in aluminium. It has also been observed in cast aluminium containing refractory $\mathrm{Ti}$ compounds that $\mathrm{TiC}$ is more effective in increasing the hardness of the composite than either $\mathrm{TiB}_{2}$ or TiN (Baturinskaya et al 1983).

It is essential to normalize these results with respect to particle sizes in order to have a fair comparison. The particle sizes of $\mathrm{TiC}, \mathrm{B}_{4} \mathrm{C}$ and $\mathrm{SiC}$ are similar. Comparing $\mathrm{TiC}$ and $\mathrm{B}_{4} \mathrm{C}$, the $\mathrm{Al} / \mathrm{TiC}$ composite appears superior in spite of the fact that $\mathrm{TiC}$ is slightly larger than $\mathrm{B}_{4} \mathrm{C}$. Among reinforcements of comparable size, TiC appears to be more effective.

Fractographs of the fractured tensile samples are shown in figure 3. They display dimples on the fracture surfaces with dimple sizes being more or less the same in all 

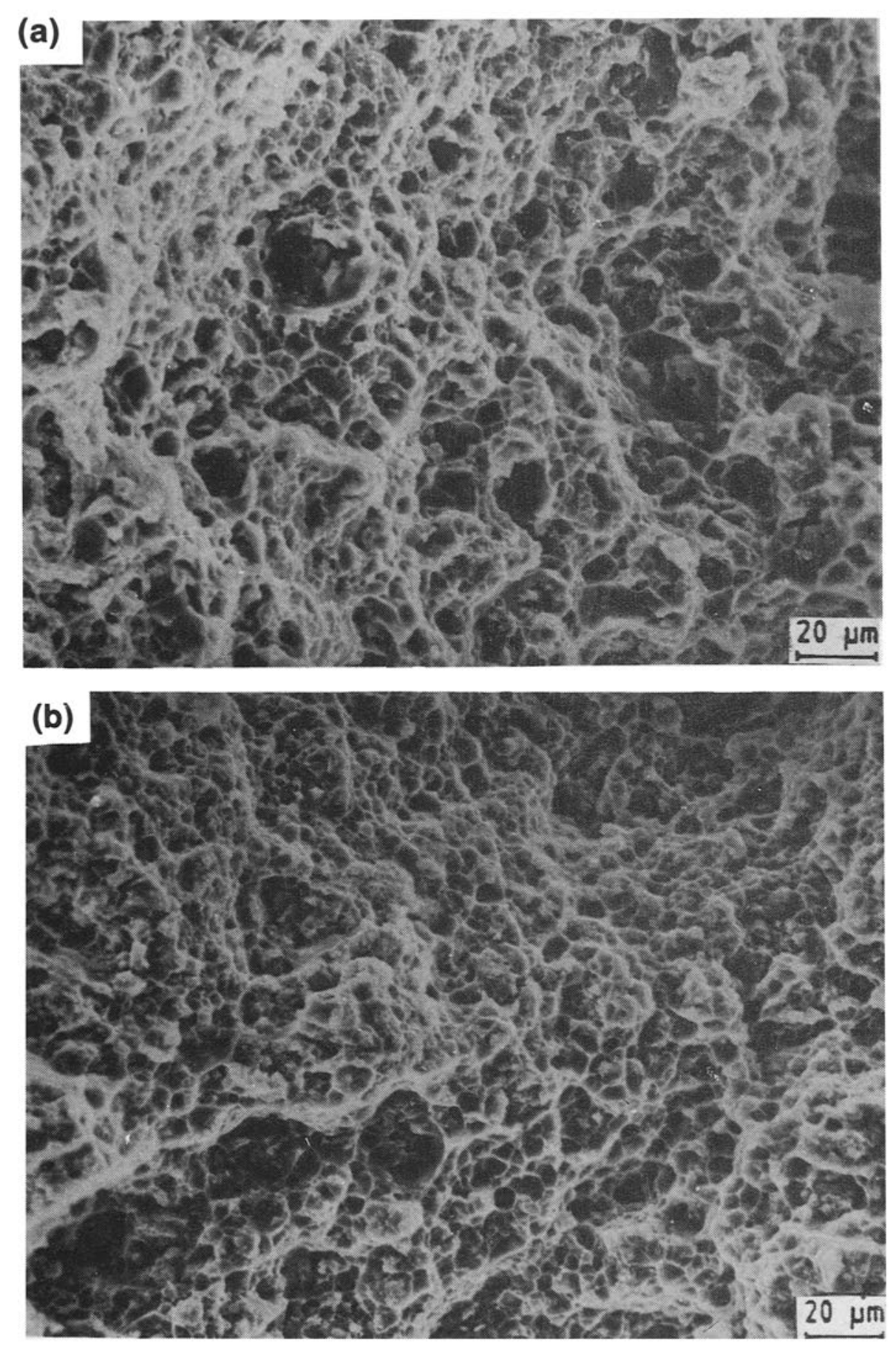

Figure 3. Fractographs of composite samples tested in tension, (a) $\mathrm{Al} / \mathrm{SiC}$, (b) $\mathrm{Al} / \mathrm{TiC}$.

the composites except that containing $\mathrm{TiB}_{2}$, in which the dimple sizes are slightly larger. This increase in the dimple size corresponds to the larger interparticle 

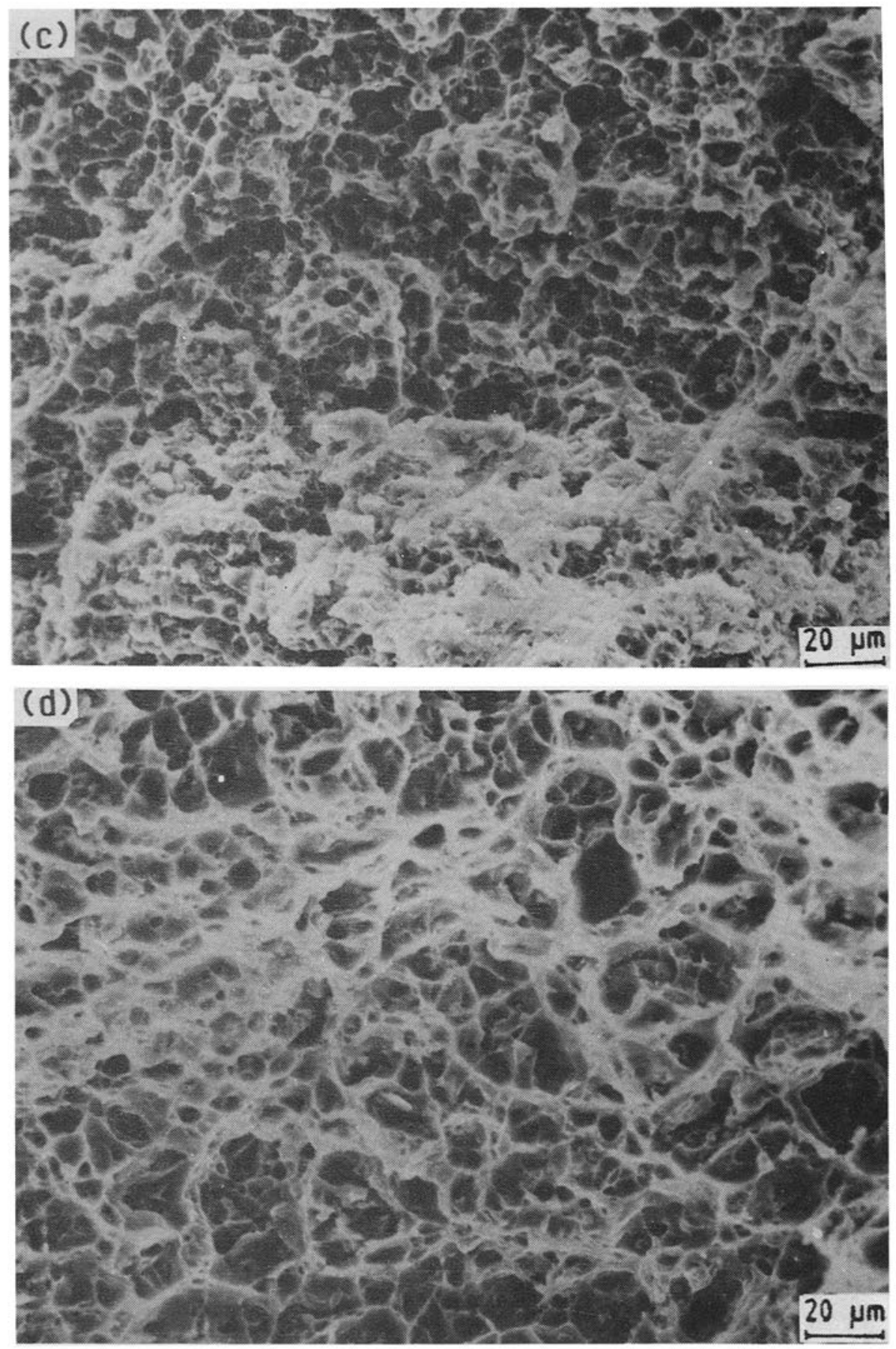

Figure 3. Fractographs of composite samples tested in tension, (c) $\mathrm{Al} / \mathrm{B}_{\mathbf{4}} \mathrm{C}$, (d) $\mathrm{Al} / \mathrm{TiB}_{2}$.

spacing as a result of the larger particle size of $\mathrm{TiB}_{2}$. It is interesting to note that the highest ductility was observed in the $\mathrm{Al} / \mathrm{TiB}_{2}$ composite which also corresponds 
to the coarsest particle sizes of the reinforcements considered. The fracture surfaces do not display major differences to show any variation in the effect of the reinforcement on the matrix.

In order to examine the interface of the reinforcement and the matrix, a sample from the $\mathrm{Al} / \mathrm{TiC}$ composite was examined in a transmission electron microscope. The $\mathrm{Al} / \mathrm{TiC}$ was chosen because of its superior properties as compared to the other composites. The electron micrograph is shown in figure 4 . It is clear from these micrographs that there is no interfacial reaction of any kind and the interface remains clearly delineated.

Any choice of reinforcement would also include a cost factor when choosing composites for most applications. A column showing the relative cost (relative to the cost of $\mathrm{SiC}$ taken as 1) per kilogram of the reinforcement is included in table 2 . It is clear from this table, that $\mathrm{SiC}$ would be the natural choice from the point of view of cost and the reasonably good properties that $\mathrm{Al} / \mathrm{SiC}$ composites display. It is interesting to note that though $\mathrm{TiC}$ is more expensive than $\mathrm{SiC}$ (by almost a factor of 2), it is still considerably cheaper than $\mathrm{B}_{4} \mathrm{C}$ (by a factor of 3 ). Considering that there is an effort to use $\mathrm{B}_{4} \mathrm{C}$ for composite strengthening in aluminium, TiC would be a more efficient choice in terms of both cost and strengthening of the matrix.

\section{Conclusion}

Four different reinforcements, namely $\mathrm{SiC}, \mathrm{TiC}, \mathrm{B}_{4} \mathrm{C}$ and $\mathrm{TiB}_{2}$ have been added to the aluminium matrix in order to evaluate their effectiveness in composite strengthening. Of the three reinforcements which have comparable particle sizes (i.e.

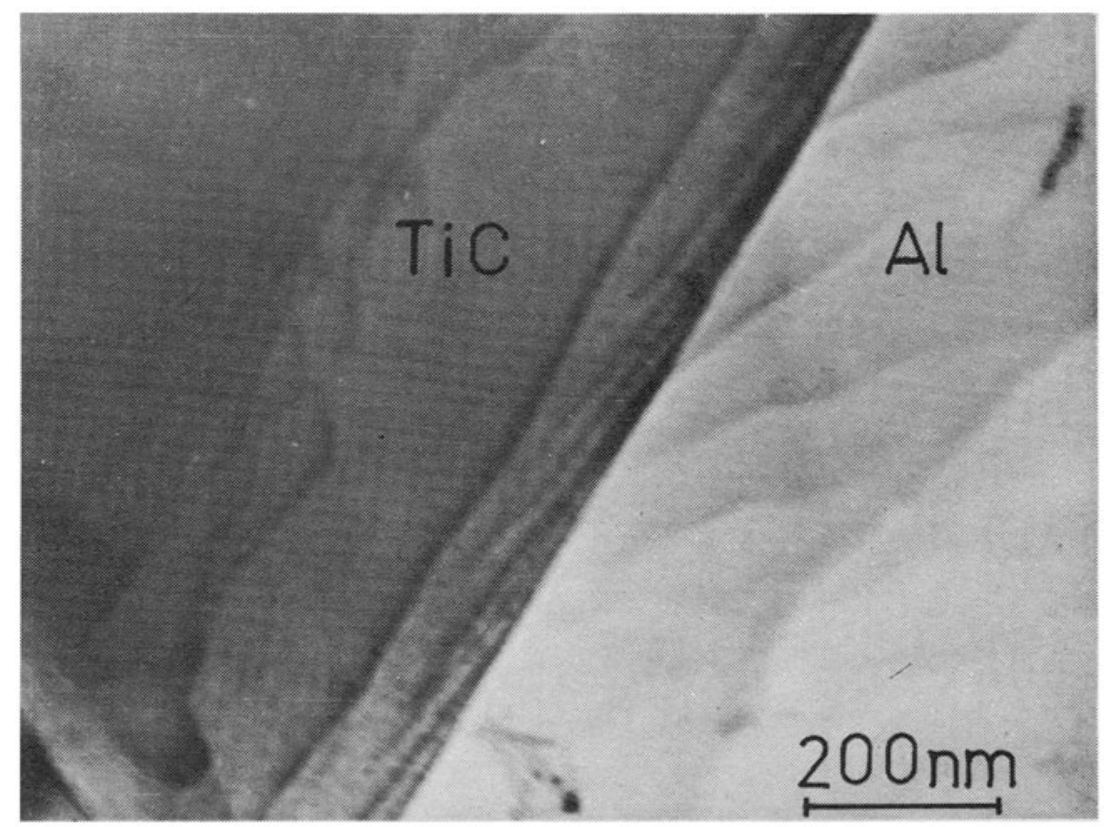

Figure 4. TEM micrograph showing the clean $\mathrm{Al} / \mathrm{TiC}$ interface. 
$\mathrm{SiC}, \mathrm{TiC}$ and $\mathrm{B}_{4} \mathrm{C}$ ), $\mathrm{TiC}$ appears to be the most potent in aluminium. A comparison of thermal expansion characteristics show that differences in the coefficients of thermal expansion between the matrix and the reinforcement does not explain the trend in strengthening observed here. In fact, the trend appears to be more consistent with the hardness values of the reinforcements. The effectiveness of TiC in composite strengthening is, therefore, most likely due to the nature of the interface in the Al-TiC system which permits an efficient transfer of load from the matrix to the reinforcement.

\section{Acknowledgements}

The authors thank Dr P Rama Rao for his encouragement in the course of this work.

\section{References}

Arsenault R J and Shi N 1986 Mater. Sci. Eng. 81175

Arsenault R J and Wu S B 1988 Scr. Metall. 22769

Baturinskaya N L, Kol'chuk N A, Servetskaya M G and Chernyi V G 1983 Izv. Akad. Nauk. SSSR Met. 3166 (Chem. Abst. 99 57356)

Chakraborty A, Bhaduri S B, Reddy J J, Mohan Rao R and Mahajan Y R 1989 Proc. ICF-7 4 Advances in fracture research (eds) $\mathrm{K}$ Salama, $\mathrm{K}$ Ravichander, D M R Taplin and P Rama Rao (Oxford: Pergamon Press) p. 2905

Chellman D J and Slaughter H C 1983 Investigation of 1100 Al alloy systems reinforced with discontinuous silicon carbides, Presented at 112th AIME Annual Meeting, Atlanta, Georgia, March 6-10, 1983

Christodoulou L, Nagle D C and Brupbacher 1986 Aluminum-ceramic composites, Int. Pat. No. WO86/06366

Divecha A D, Fishman S G and Karmarkar S D 1981 J. Met. 3312

Dolowy J F 1986 Light Met. Age 44(6) 9

Girot F A, Quenisset J M and Naslain 1987 Compos. Sci. Technol. 30155

Kingery W D, Bowen H K and Uhlmann D R 1976 Introduction to ceramics (New York: John Wiley \& Sons) p. 595

Lynch J F, Ruderer C G and Duckworth W H 1966 Engineering properties of selected ceramic materials (Columbus, Ohio: Am. Ceram. Soc.)

Macdonald N F and Ransley C E 1954 Proc. of Symp. on Powder Metallurgy Metal Powder for Engineering purposes (London: The Iron and Steel Institute and Institute of Metals)

Mccoy J W, Jones C and Wawner F E 1988 SAMPE Q. 19(2) 37

Nair S V, Tien J K and Bates R C 1985 Int. Metall. Rev. 30275

Nieh T G and Chellman D J 1984 Scr. Metall. 18925

Singer A R E and Ozbek S 1985 Powder Metall. 28(2) 72

Slater H K and Coon P M 1988 Proc. Fourth Int. Al extrusion Tech: Seminar, 2, Chicago (Washington D.C.: The Aluminum Association) p. 525 